\title{
Analytical Results of MOX Colemanite Concrete Samples Poured August 29, 2012
}

D.R. Best

A.D. Cozzi

M.M. Reigel

December 2012

Savannah River National Laboratory Savannah River Nuclear Solutions, LLC Aiken, SC 29808

Prepared for the U.S. Department of Energy under contract number DE-AC09-08SR22470. 


\section{DISCLAIMER}

This work was prepared under an agreement with and funded by the U.S. Government. Neither the U.S. Government or its employees, nor any of its contractors, subcontractors or their employees, makes any express or implied:

1. warranty or assumes any legal liability for the accuracy, completeness, or for the use or results of such use of any information, product, or process disclosed; or

2. representation that such use or results of such use would not infringe privately owned rights; or

3. endorsement or recommendation of any specifically identified commercial product, process, or service.

Any views and opinions of authors expressed in this work do not necessarily state or reflect those of the United States Government, or its contractors, or subcontractors.

\section{Printed in the United States of America \\ Prepared for U.S. Department of Energy}


Keywords: MOX Colemanite Concrete

Retention: Permanent

\section{Analytical Results of MOX Colemanite Concrete Samples Poured August 29, 2012}

D.R. Best

A.D. Cozzi

M.M. Reigel

December 2012

Savannah River National Laboratory Savannah River Nuclear Solutions, LLC Aiken, SC 29808

Prepared for the U.S. Department of Energy under contract number DE-AC09-08SR22470. 


\section{REVIEWS AND APPROVALS}

AUTHORS:

D.R. Best, Engineering Process Development

Date

A.D. Cozzi, Engineering Process Development

Date

M.M. Reigel, Engineering Process Development

Date

TECHNICAL REVIEW:

B.R. Pickenheim, Engineering Process Development

Date

APPROVAL:

K.M. Fox, Manager

Date

Engineering Process Development

S.L. Marra, Manager

Date

E\&CPT Research Programs 


\begin{tabular}{|c|c|c|}
\hline \multicolumn{3}{|c|}{ LIST OF REVISIONS } \\
\hline $\begin{array}{l}\text { Revision } \\
\text { Number }\end{array}$ & Summary of Changes & Date \\
\hline 1 & $\begin{array}{l}\text { Corrected the reported average boron content and partial boron } \\
\text { density }\end{array}$ & $12 / 19 / 12$ \\
\hline & & \\
\hline & & \\
\hline & & \\
\hline & & \\
\hline & & \\
\hline & & \\
\hline & & \\
\hline & & \\
\hline & & \\
\hline & & \\
\hline & & \\
\hline & & \\
\hline & & \\
\hline & & \\
\hline & & \\
\hline & & \\
\hline & & \\
\hline & & \\
\hline & & \\
\hline & & \\
\hline & & \\
\hline
\end{tabular}




\section{EXECUTIVE SUMMARY}

The Mixed Oxide Fuel Fabrication Facility (MFFF) will use colemanite bearing concrete neutron absorber panels credited with attenuating neutron flux in the criticality design analyses and shielding operators from radiation. The Savannah River National Laboratory is tasked with measuring the total density, partial hydrogen density, and partial boron density of the colemanite concrete.

Samples poured 8/29/12 were received on 9/20/2012 and analyzed. The average total density of each of the samples measured by the ASTM method C 642 was within the lower bound of $1.88 \mathrm{~g} / \mathrm{cm}^{3}$. The average partial hydrogen density of samples 8.6.1, 8.7.1, and 8.5.3 as measured using method ASTM E 1311 met the lower bound of $6.04 \mathrm{E}-02 \mathrm{~g} / \mathrm{cm}^{3}$. The average measured partial boron density of each sample met the lower bound of $1.65 \mathrm{E}-01 \mathrm{~g} / \mathrm{cm}^{3}$ measured by the ASTM C 1301 method. The average partial hydrogen density of samples 8.5.1, 8.6.3, and 8.7.3 did not meet the lower bound. The samples, as received, were not wrapped in a moist towel as previous samples and appeared to be somewhat drier. This may explain the lower hydrogen partial density with respect to previous samples.

\begin{tabular}{|c|c|c|c|c|c|c|}
\hline \multirow{2}{*}{$\begin{array}{c}\text { Sample } \\
\text { ID }\end{array}$} & \multicolumn{2}{|c|}{$\begin{array}{l}\text { Total Density Lower } \\
\text { Bound }\left(\mathrm{g} / \mathrm{cm}^{3}\right)\end{array}$} & \multicolumn{2}{|c|}{$\begin{array}{c}\text { Hydrogen Partial Density } \\
\text { Lower Bound }\left(\mathrm{g} / \mathrm{cm}^{3}\right)\end{array}$} & \multicolumn{2}{|c|}{$\begin{array}{l}\text { Boron Partial Density } \\
\text { Lower Bound }\left(\mathrm{g} / \mathrm{cm}^{3}\right)\end{array}$} \\
\hline & Limit & Measured & Limit & Measured & Limit & Measured \\
\hline 8.5 .1 & \multirow{6}{*}{1.88} & 2.11 & \multirow{6}{*}{ 6.04E-02 } & $5.24 \mathrm{E}-02$ & \multirow{6}{*}{$1.65 \mathrm{E}-01$} & $1.76 \mathrm{E}-01$ \\
\hline 8.6 .1 & & 2.10 & & 6.35E-02 & & 1.85E-01 \\
\hline 8.7 .1 & & 2.11 & & 6.59E-02 & & 1.89E-01 \\
\hline 8.5 .3 & & 2.10 & & 6.19E-02 & & 1.83E-01 \\
\hline 8.6 .3 & & 2.08 & & $5.60 \mathrm{E}-02$ & & $1.83 \mathrm{E}-01$ \\
\hline 8.7 .3 & & 2.12 & & 5.69E-02 & & $1.87 \mathrm{E}-01$ \\
\hline
\end{tabular}


TABLE OF CONTENTS

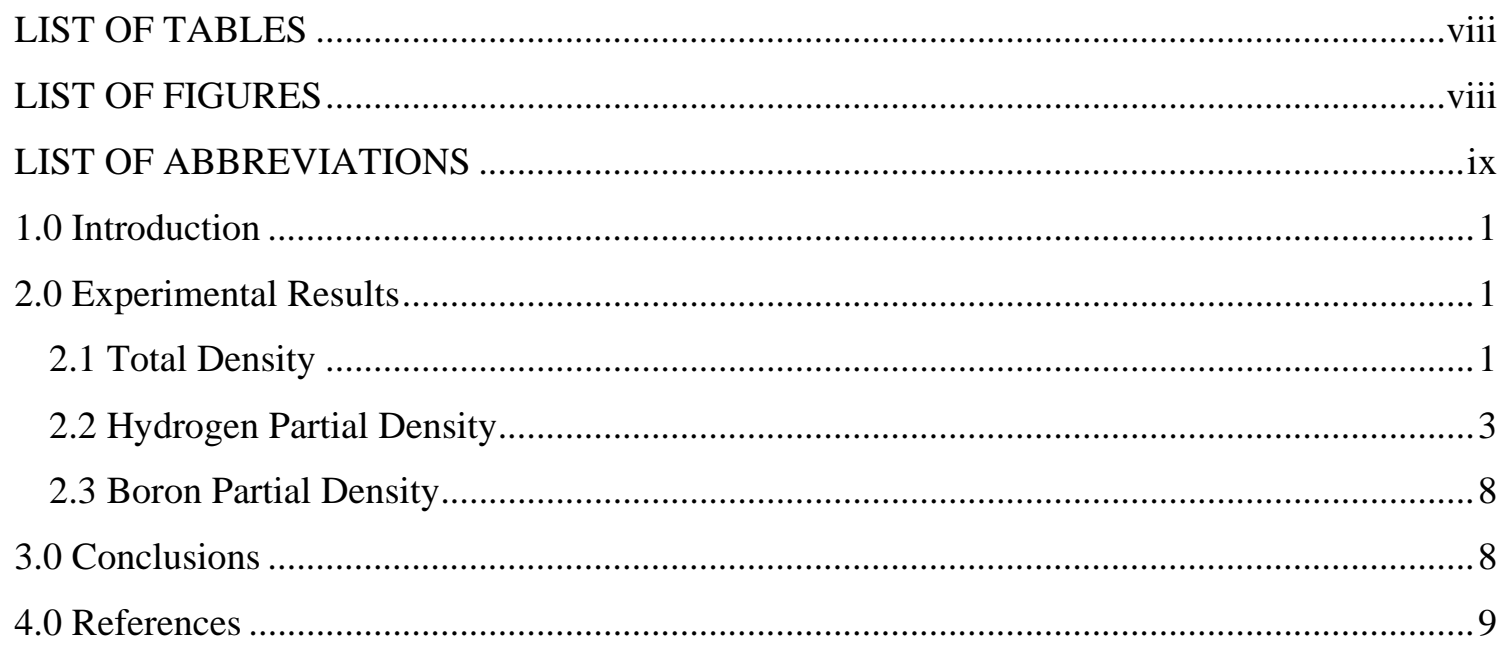




\section{LIST OF TABLES}

Table 1. Acceptable Material Neutron Absorber Characteristics.................................................1

Table 2. Mass Measurements of Subsamples After Each Treatment..........................................2

Table 3. Calculated Results of Equations 1-7 for the Colemanite Concrete. ................................

Table 4. Mass loss from $25-650{ }^{\circ} \mathrm{C}$ for samples poured on August 29 and received on

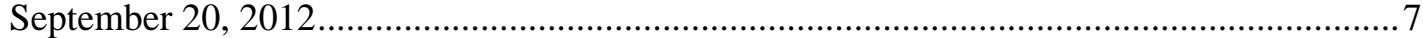

Table 5. Boron Results of Colemanite Concrete Analyzed using ASTM C 1301........................8

Table 6. Lower Bounds and Average Measured Values for the Total Density, Hydrogen Partial Density, and Boron Partial Density for the Colemanite Concrete Samples Poured 8/29/2012.

\section{LIST OF FIGURES}

Figure 1. TGA curve showing the mass loss of sample 8.5.1 ….............................................4

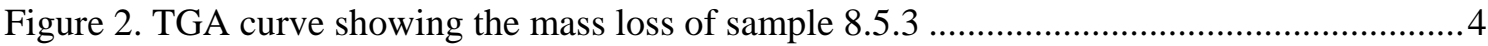

Figure 3. TGA curve showing the mass loss of sample 8.6.1 …...........................................5

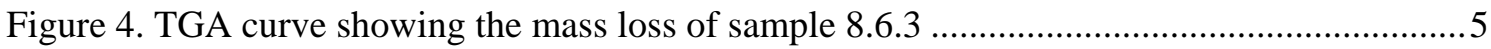

Figure 5. TGA curve showing the mass loss of sample 8.7.1 ..................................................6

Figure 6. TGA curve showing the mass loss of sample 8.7.3 …...........................................6 


\section{LIST OF ABBREVIATIONS}

$\begin{array}{ll}\text { DSC } & \text { Differential Scanning Calorimetry } \\ \text { ICP } & \text { Inductively Coupled Plasma } \\ \text { MFFF } & \text { Mixed Oxide Fuel Fabrication Facility } \\ \text { OES } & \text { Optical Emission Spectrometer } \\ \text { PSAL } & \text { Process Science Analytical Laboratory } \\ \text { SRNL } & \text { Savannah River National Laboratory } \\ \text { TGA } & \text { Thermal Gravimetric Analysis }\end{array}$




\subsection{Introduction}

The Mixed Oxide Fuel Fabrication Facility (MFFF) will use colemanite bearing concrete neutron absorber panels credited with attenuating neutron flux in the criticality design analyses and shielding the operator from radiation ${ }^{1}$. Table 1 is an excerpt from Table 2.1.2.3 in Reference 1.

Table 1. Acceptable Material Neutron Absorber Characteristics.

\begin{tabular}{|c|c|c|c|}
\hline Material Type & $\begin{array}{l}\text { Total Density Lower } \\
\text { Bound }\left(\mathrm{g} / \mathrm{cm}^{3}\right)\end{array}$ & $\begin{array}{l}\text { Hydrogen Partial Density } \\
\text { Lower Bound }\left(\mathrm{g} / \mathrm{cm}^{3}\right)\end{array}$ & $\begin{array}{l}\text { Boron Partial Density } \\
\text { Lower Bound }\left(\mathrm{g} / \mathrm{cm}^{3}\right)\end{array}$ \\
\hline $\begin{array}{l}\text { Borated Concrete } \\
\text { (Colemanite) }\end{array}$ & 1.88 & $6.04 \mathrm{E}-02$ & 1.65E-01 \\
\hline
\end{tabular}

The Savannah River National Laboratory is tasked with measuring the properties of the colemanite concrete identified in Table $1^{2}$.

\subsection{Experimental Results}

Samples poured on 8/29/2012 were received on 9/20/2012. The samples were either $40 \mathrm{~mm}$ cubes or a parallelepiped approximately $40 \mathrm{~mm} \times 40 \mathrm{~mm}$ x $80 \mathrm{~mm}$. The samples arrived in individual plastic zip top bags and exhibited sign of drying. This condition was contrary to the previous set of cubes which arrived wrapped in moist paper towels. ${ }^{3}$

\subsection{Total Density}

The total density of each of the samples was determined by the ASTM method for density in hardened concrete ${ }^{4}$. The sample was crushed to obtain duplicate subsamples for the density determination.

The ASTM method was followed with the exception of sample size. Section 4.1 of the ASTM procedure specifies a sample size of approximately 800 grams. As the samples themselves weighed less than 300 grams, a reduced sample size was used.

Mass measurements were taken after each treatment with the masses being designated A through $\mathrm{D}$, where;

$\mathrm{A}=$ mass of oven-dried sample in air between 100 to $110^{\circ} \mathrm{C}, \mathrm{g}$

$\mathrm{B}=$ mass of surface-dry sample in air after immersion, $\mathrm{g}$

$\mathrm{C}=$ mass of surface-dry sample in air after immersion and boiling, $\mathrm{g}$

$\mathrm{D}=$ apparent mass of sample in water after immersion and boiling, g, Table 2 . 
Table 2. Mass Measurements of Subsamples After Each Treatment.

\begin{tabular}{|c|c|c|c|c|}
\hline Subsample & A (g) & B (g) & C (g) & D (g) \\
\hline Treatment & dry & saturated & boil/saturated & suspended \\
\hline Date & $30-$ Sep-12 & 2 -Oct-12 & 3-Oct-12 & 3-Oct-12 \\
\hline \hline $8.5 .1-1$ & 18.625 & 21.492 & 21.5287 & 11.3116 \\
\hline $8.5 .1-2$ & 15.624 & 18.025 & 18.0536 & 9.5016 \\
\hline $8.6 .1-1$ & 17.831 & 20.531 & 20.5992 & 10.8110 \\
\hline $8.6 .1-2$ & 15.229 & 17.524 & 17.5130 & 9.1760 \\
\hline $8.7 .1-1$ & 24.283 & 28.024 & 28.0157 & 14.7077 \\
\hline $8.7 .1-2$ & 9.897 & 11.351 & 11.3512 & 5.9754 \\
\hline $8.5 .3-1$ & 12.678 & 14.333 & 14.3457 & 7.5753 \\
\hline $8.5 .3-2$ & 10.463 & 12.058 & 12.0599 & 6.2922 \\
\hline $8.6 .3-1$ & 15.676 & 18.088 & 18.1217 & 9.5113 \\
\hline $8.6 .3-2$ & 10.562 & 12.319 & 12.3023 & 6.3343 \\
\hline $8.7 .3-1$ & 18.497 & 21.178 & 21.1416 & 11.1670 \\
\hline $8.7 .3-2$ & 11.734 & 13.481 & 13.4235 & 7.0748 \\
\hline
\end{tabular}

Using the calculations in the ASTM method, the following properties were calculated:

Absorption after immersion, $\%=\frac{B-A}{A} \times 100$,

Absorption after immersion and boiling, $\%=\frac{C-A}{A} \times 100$,

Bulk density, dry $=\frac{A}{C-D} \times \rho$,

Bulk density after immersion $=\frac{B}{C-D} \times \rho$,

Bulk density after immersion and boiling $=\frac{C}{C-D} \times \rho$,

Apparent density $=\frac{A}{A-D} \times \rho$,

Volume of permeable pore space $=\frac{C-A}{C-D} \times 100$

The density used in these calculations is that of water, $\left(\sim 1 \mathrm{~g} / \mathrm{cm}^{3}\right)$. The results of the calculations performed with Equations 1-7 are tabulated and averaged in Table 3. 
Table 3. Calculated Results of Equations 1-7 for the Colemanite Concrete.

\begin{tabular}{|c|c|c|c|c|c|c|c|}
\hline $\begin{array}{l}\text { Sample } \\
\text { ID }\end{array}$ & $\begin{array}{c}\text { Absorption } \\
\text { Eq (1) } \\
\text { (\%) }\end{array}$ & $\begin{array}{c}\text { Absorption } \\
\text { Eq (2) } \\
\text { (\%) }\end{array}$ & $\begin{array}{c}\text { Bulk } \\
\text { Density } \\
\text { Eq (3) } \\
\left(\mathrm{g} / \mathrm{cm}^{3}\right)\end{array}$ & $\begin{array}{c}\text { Bulk } \\
\text { Density } \\
\text { Eq (4) } \\
\left(\mathrm{g} / \mathrm{cm}^{3}\right)\end{array}$ & $\begin{array}{c}\text { Bulk } \\
\text { Density } \\
\text { Eq (5) } \\
\left(\mathrm{g} / \mathrm{cm}^{3}\right)\end{array}$ & $\begin{array}{c}\text { Apparent } \\
\text { Density } \\
\text { Eq (6) } \\
\left(\mathrm{g} / \mathrm{cm}^{3}\right)\end{array}$ & $\begin{array}{c}\text { Permeable } \\
\text { void \% } \\
\text { Eq (7) }\end{array}$ \\
\hline 8.5.1-1 & 15.39 & 15.59 & 1.82 & 2.10 & 2.11 & 2.55 & 28.42 \\
\hline 8.5.1-2 & 15.37 & 15.55 & 1.83 & 2.11 & 2.11 & 2.55 & 28.41 \\
\hline 8.5.1 avg & 15.38 & 15.57 & 1.82 & 2.11 & 2.11 & 2.55 & 28.41 \\
\hline 8.6.1-1 & 15.14 & 15.52 & 1.82 & 2.10 & 2.10 & 2.54 & 28.28 \\
\hline 8.6.1-2 & 15.07 & 15.00 & 1.83 & 2.10 & 2.10 & 2.52 & 27.40 \\
\hline $8.6 .1 \mathrm{avg}$ & 15.11 & 15.26 & 1.82 & 2.10 & 2.10 & 2.53 & 27.84 \\
\hline 8.7.1-1 & 15.41 & 15.37 & 1.82 & 2.11 & 2.11 & 2.54 & 28.05 \\
\hline $8.7 .1-2$ & 14.69 & 14.69 & 1.84 & 2.11 & 2.11 & 2.52 & 27.05 \\
\hline 8.7.1 avg & 15.05 & 15.03 & 1.83 & 2.11 & 2.11 & 2.53 & 27.55 \\
\hline 8.5.3-1 & 13.05 & 13.15 & 1.87 & 2.12 & 2.12 & 2.48 & 24.63 \\
\hline 8.5.3-2 & 15.24 & 15.26 & 1.81 & 2.09 & 2.09 & 2.51 & 27.69 \\
\hline 8.5.3 avg & 14.15 & 14.21 & 1.84 & 2.10 & 2.10 & 2.50 & 26.16 \\
\hline 8.6.3-1 & 15.39 & 15.60 & 1.82 & 2.10 & 2.10 & 2.54 & 28.40 \\
\hline 8.6.3-2 & 16.64 & 16.48 & 1.77 & 2.06 & 2.06 & 2.50 & 29.16 \\
\hline $8.6 .3 \mathrm{avg}$ & 16.01 & 16.04 & 1.80 & 2.08 & 2.08 & 2.52 & 28.78 \\
\hline 8.7.3-1 & 14.49 & 14.30 & 1.85 & 2.12 & 2.12 & 2.52 & 26.51 \\
\hline 8.7.3-2 & 14.89 & 14.40 & 1.85 & 2.12 & 2.11 & 2.52 & 26.61 \\
\hline 8.7.3 avg & 14.69 & 14.35 & 1.85 & 2.12 & 2.12 & 2.52 & 26.56 \\
\hline
\end{tabular}

Equations (4) and (5) are the most appropriate to represent the density of the Colemanite concrete as the concrete is saturated with water during placement.

\subsection{Hydrogen Partial Density}

The hydrogen partial density of the colemanite concrete was determined using the ASTM method for determining volatile content using thermogravimetric analysis ${ }^{5}$. The ASTM E 1131-08 defines highly volatile matter as components that will volatilize $<200^{\circ} \mathrm{C}$ and medium volatile matter as components that will degrade or volatilize in the range $200-750{ }^{\circ} \mathrm{C}$. In an evaluation of the thermal decomposition of colemanite, Waclawska et al, determined that the release of water from colemanite was complete at $600{ }^{\circ} \mathrm{C}$ and that melting and crystallization of a calcium borate phase occurred above $650{ }^{\circ} \mathrm{C}^{6}$. A Netzsch STA 409 Luxx, which couples Differential Scanning Calorimetry (DSC) with Thermal Gravimetric Analysis (TGA), was used for TGA of the colemanite concrete samples. After loading the sample, the chamber was purged with nitrogen at $60 \mathrm{ml} / \mathrm{min}$ prior to heating. Triplicate samples of 8.5.1, 8.5.3, 8.6.1, 8.6.3, 8.7.1, and 8.7.3 were heated at $5{ }^{\circ} \mathrm{C} / \mathrm{min}$ up to $650{ }^{\circ} \mathrm{C}$ in a flowing nitrogen atmosphere of $60 \mathrm{ml} / \mathrm{min}$ (Figure 1 - Figure 6 ). The initial mass loss is associated with the free water from the mix. The second mass loss beginning below $400{ }^{\circ} \mathrm{C}$ is due to the thermal decomposition of the colemanite. Table 4 summarizes the mass change and hydrogen partial density for all six samples. 


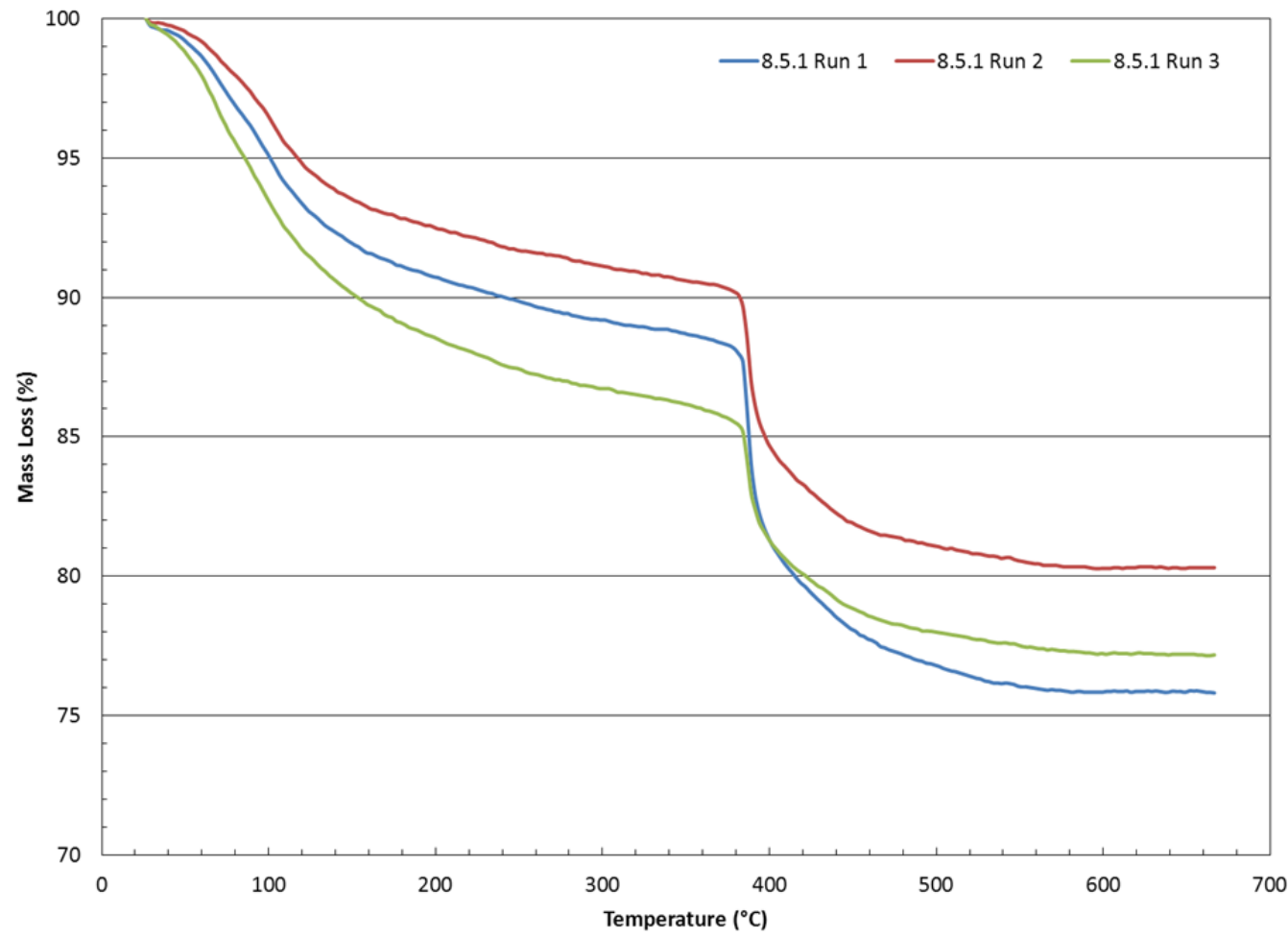

Figure 1. TGA curve showing the mass loss of sample 8.5.1

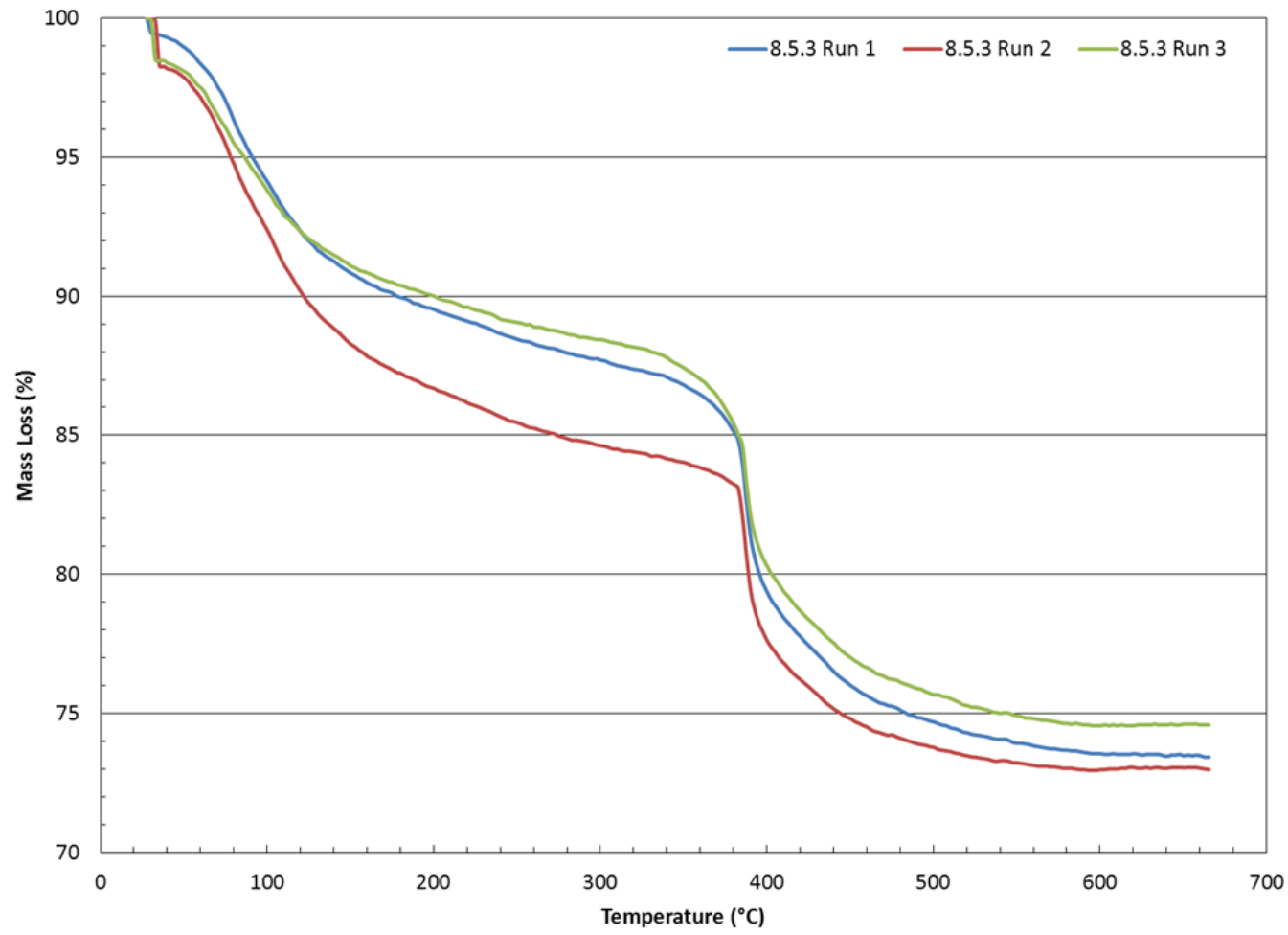

Figure 2. TGA curve showing the mass loss of sample 8.5.3 


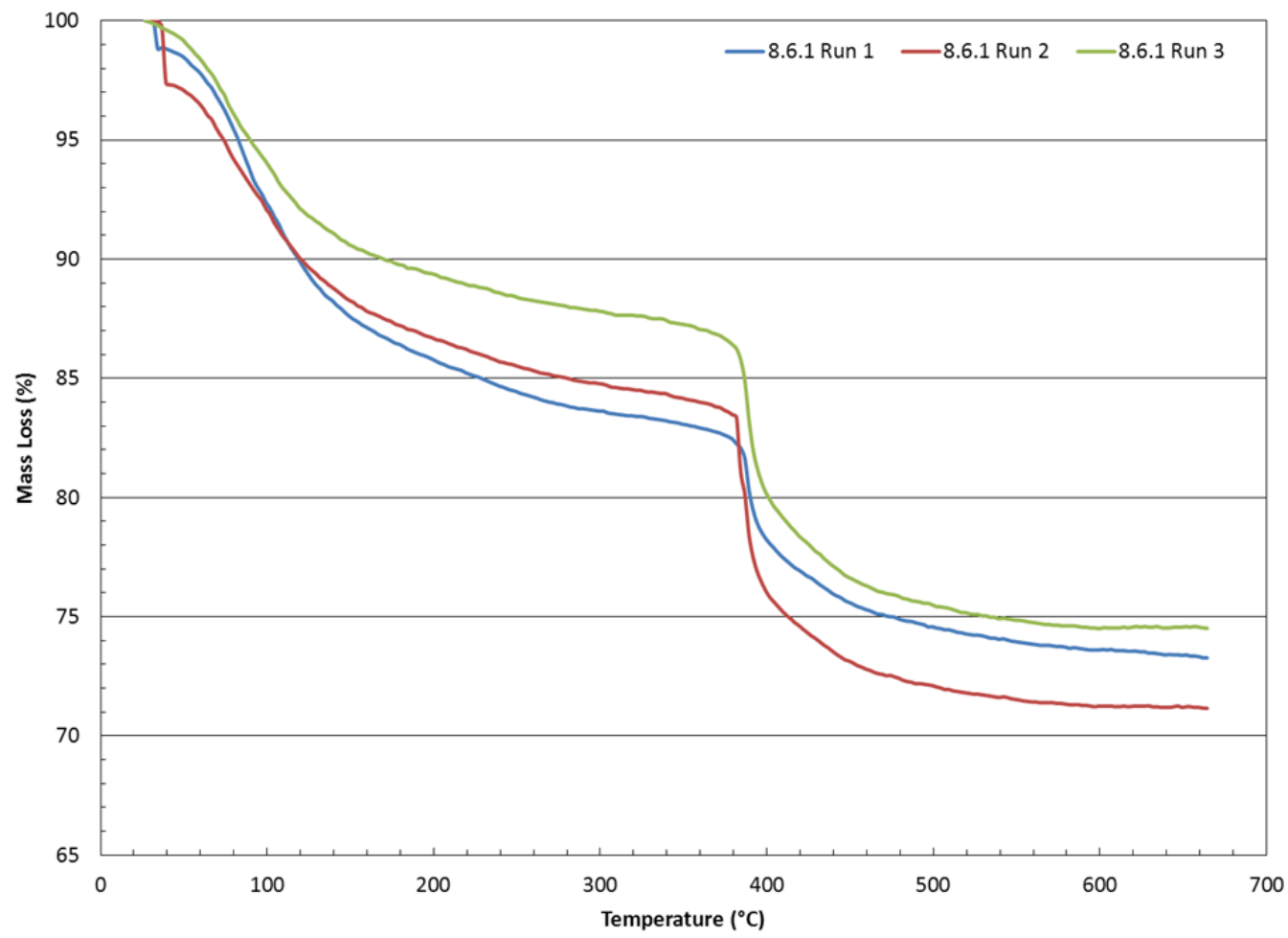

Figure 3. TGA curve showing the mass loss of sample 8.6.1

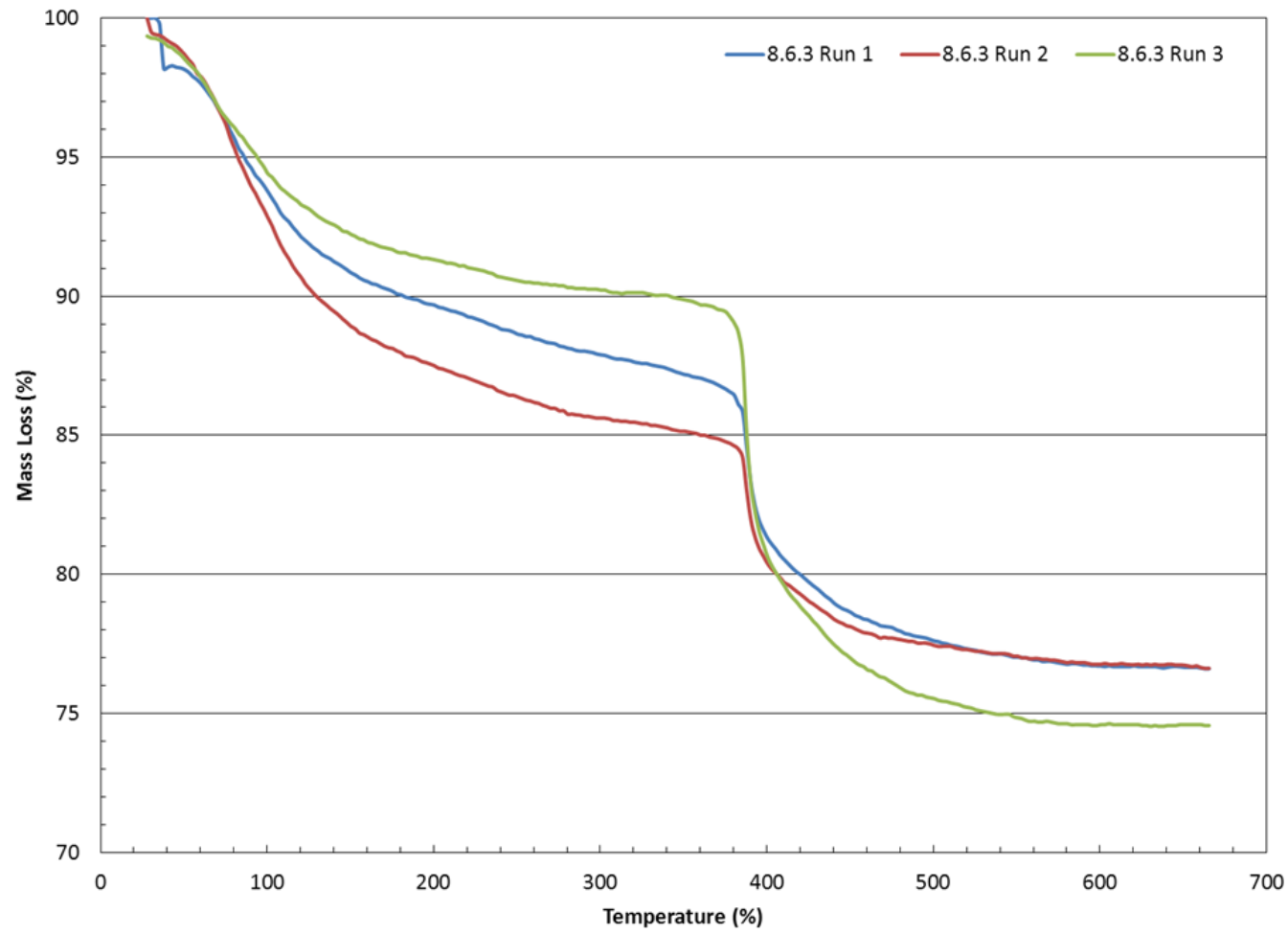

Figure 4. TGA curve showing the mass loss of sample 8.6.3 


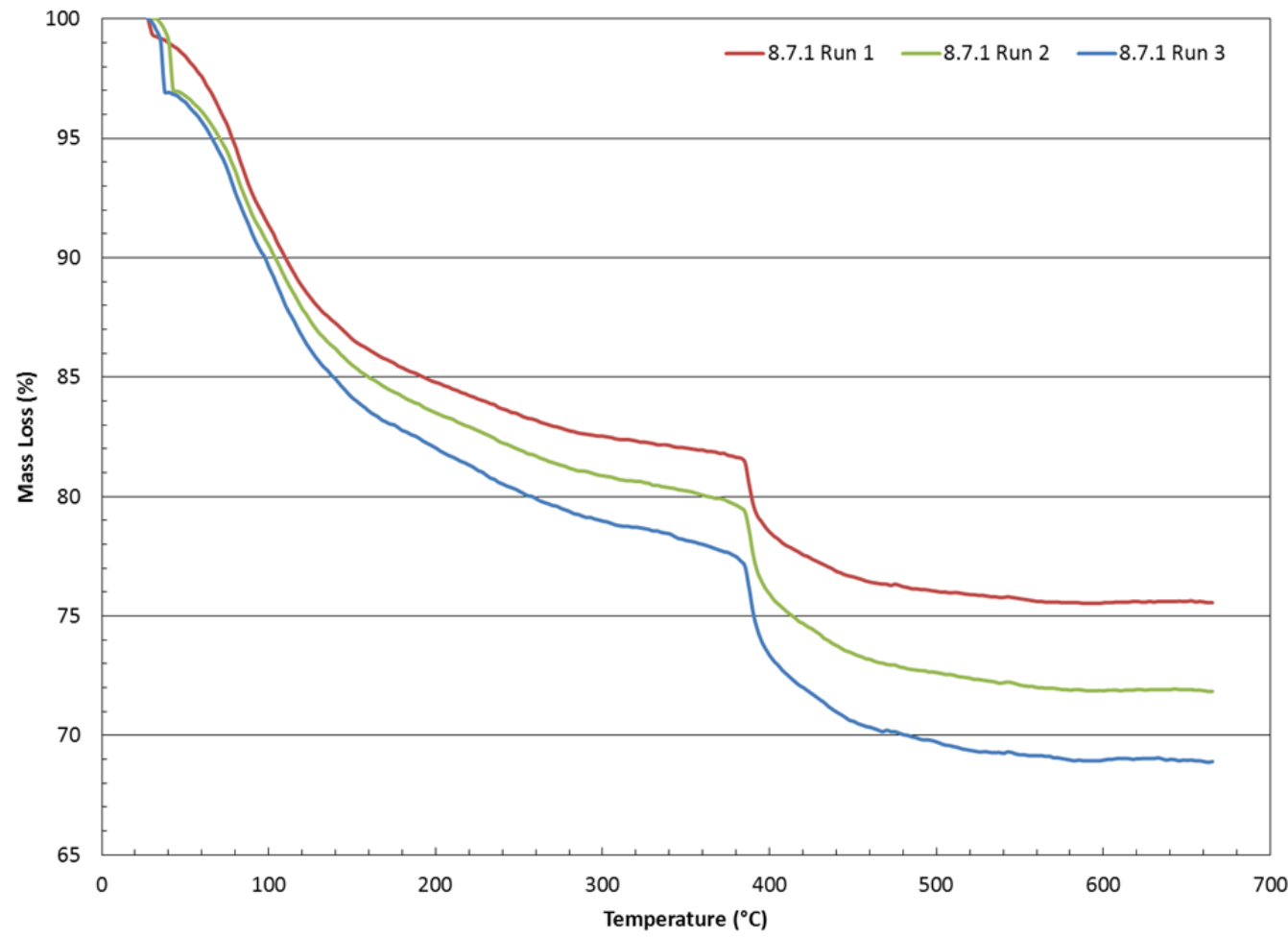

Figure 5. TGA curve showing the mass loss of sample 8.7.1

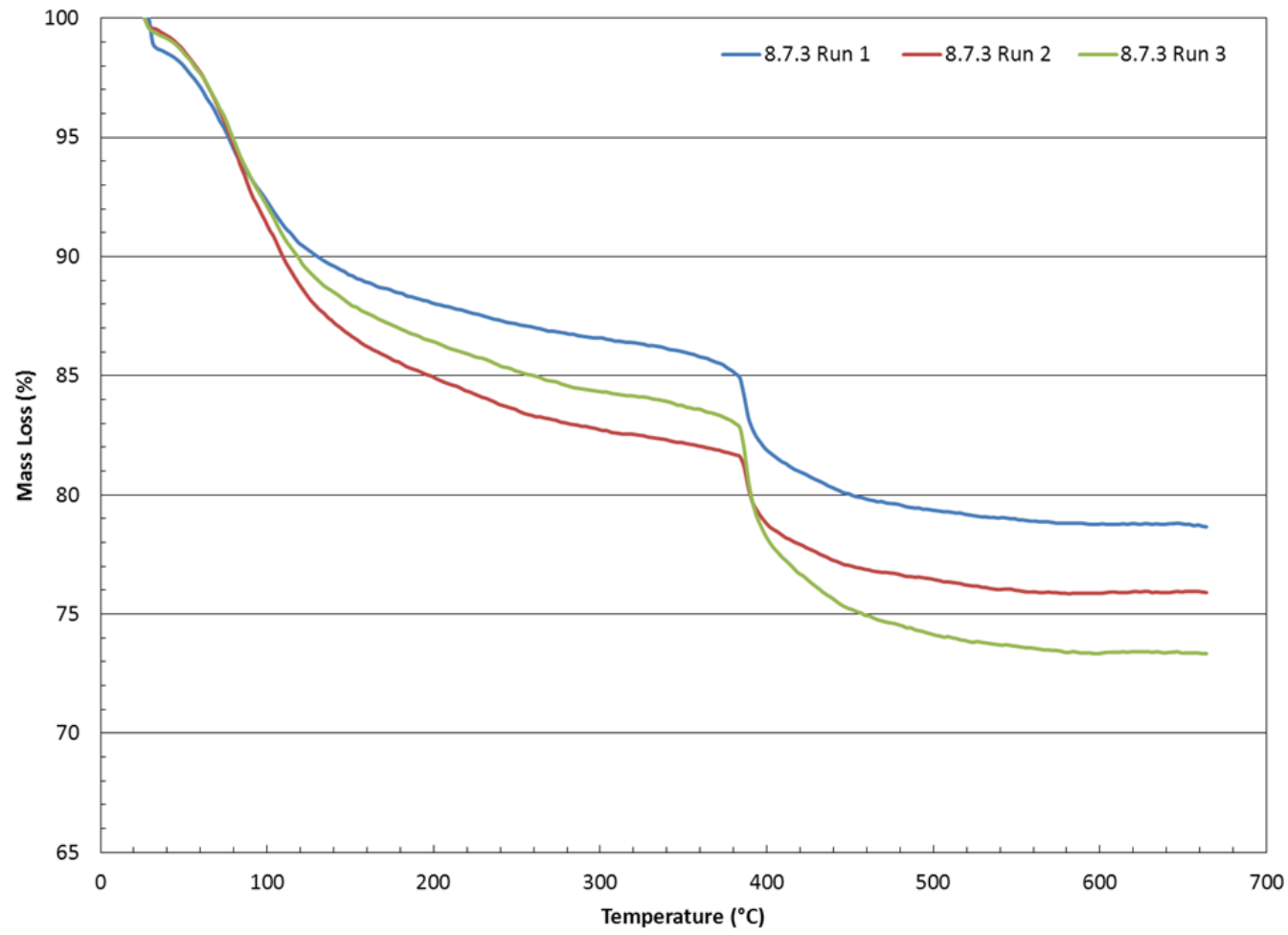

Figure 6. TGA curve showing the mass loss of sample 8.7.3 
Table 4. Mass loss from $25-650{ }^{\circ} \mathrm{C}$ for samples poured on August 29 and received on September 20, 2012

\begin{tabular}{|c|c|c|c|c|c|c|}
\hline $\begin{array}{l}\text { Sample } \\
\text { ID }\end{array}$ & $\underset{\#}{\text { Run }}$ & $\begin{array}{c}\text { Mass Loss } \\
(\%) \\
25-175^{\circ} \mathrm{C}\end{array}$ & $\begin{array}{c}\text { Mass Loss } \\
(\%) \\
300-600{ }^{\circ} \mathrm{C}\end{array}$ & $\begin{array}{c}\text { Total Mass } \\
\text { Loss (\%) }\end{array}$ & $\begin{array}{c}\text { Average } \\
\text { Total Mass } \\
\text { Loss (\%) }\end{array}$ & $\begin{array}{c}\text { Total Hydrogen } \\
\text { Partial Density } \\
\left(\mathrm{g} / \mathrm{cm}^{3}\right)\end{array}$ \\
\hline \multirow{3}{*}{ 8.5.1 } & 1 & 10.77 & 9.53 & 22.83 & \multirow{3}{*}{22.20} & \multirow{3}{*}{$5.24 \mathrm{E}-02$} \\
\hline & 2 & 8.71 & 13.36 & 24.14 & & \\
\hline & 3 & 7.03 & 10.86 & 19.64 & & \\
\hline \multirow{3}{*}{ 8.5.3 } & 1 & 9.90 & 14.15 & 26.58 & \multirow{3}{*}{26.35} & \multirow{3}{*}{$6.19 \mathrm{E}-02$} \\
\hline & 2 & 12.63 & 11.68 & 27.05 & & \\
\hline & 3 & 9.50 & 13.86 & 25.42 & & \\
\hline \multirow{3}{*}{ 8.6.1 } & 1 & 13.43 & 10.03 & 26.75 & \multirow{3}{*}{27.02} & \multirow{3}{*}{ 6.35E-02 } \\
\hline & 2 & 12.64 & 13.53 & 28.83 & & \\
\hline & 3 & 10.13 & 13.29 & 25.48 & & \\
\hline \multirow{3}{*}{ 8.6.3 } & 1 & 9.82 & 11.24 & 23.39 & \multirow{3}{*}{24.07} & \multirow{3}{*}{$5.60 \mathrm{E}-02$} \\
\hline & 2 & 11.88 & 8.85 & 23.38 & & \\
\hline & 3 & 8.31 & 15.63 & 25.44 & & \\
\hline \multirow{3}{*}{ 8.7.1 } & 1 & 14.42 & 6.97 & 24.44 & \multirow{3}{*}{27.90} & \multirow{3}{*}{$6.59 \mathrm{E}-02$} \\
\hline & 2 & 15.63 & 9.00 & 28.16 & & \\
\hline & 3 & 17.00 & 10.00 & 31.09 & & \\
\hline \multirow{3}{*}{ 8.7.3 } & 1 & 11.42 & 7.82 & 21.34 & \multirow{3}{*}{23.98} & \multirow{3}{*}{ 5.69E-02 } \\
\hline & 2 & 14.18 & 6.85 & 23.95 & & \\
\hline & 3 & 12.89 & 10.97 & 26.66 & & \\
\hline
\end{tabular}

In order to calculate the hydrogen partial density, it is assumed the average total mass loss for each sample in Table 4 is due to water, both free and from the decomposition of colemanite. The hydrogen partial density is calculated from the average mass loss (Table 4) and density of the sample (Table 3) as shown in the following equations. The numbers from sample 8.5.3 are used as an example calculation.

$$
\begin{aligned}
& \text { Moles } \mathrm{H}_{2} \mathrm{O} \text { in } 100 \mathrm{~g} \text { concrete }=\frac{\text { mass fraction } \mathrm{H}_{2} \mathrm{O}}{M \mathrm{H}_{2} \mathrm{O}}=\frac{26.35 \frac{\mathrm{g} \mathrm{H} \mathrm{H}_{2} \mathrm{O}}{\mathrm{gconcrete}}}{18.015 \mathrm{~g} \mathrm{~mol} \mathrm{H}_{2} \mathrm{O}}=1.46 \mathrm{molH}_{2} \mathrm{O}, \\
& \frac{\mathrm{g} \mathrm{H}}{\text { Mole } \mathrm{H}_{2} \mathrm{O}}=2.016 \mathrm{~g} \mathrm{H}, \\
& \mathrm{g} \mathrm{H} \text { in } 100 \mathrm{~g} \text { concrete }=1.46 \mathrm{~mol} \mathrm{H}_{2} \mathrm{O} \times 2.016 \mathrm{~g} \mathrm{H}=2.94 \mathrm{~g} \mathrm{H}, \\
& \text { Volume concrete }=\frac{\text { mass concrete }}{\text { density concrete }}=\frac{100 \mathrm{~g} \text { concrete }}{2.10 \frac{\mathrm{g}}{\mathrm{ml}}}=47.62 \mathrm{ml} \text { concrete, } \\
& \mathrm{H} \text { density } \frac{\mathrm{g}}{\mathrm{ml}}=\frac{\text { mass } \mathrm{H}}{\text { volume concrete }}=\frac{2.94 \mathrm{~g} \mathrm{H}}{47.62 \mathrm{ml} \mathrm{concrete}}=6.19 \mathrm{E}-02 \frac{\mathrm{g} \mathrm{H}}{\mathrm{ml} \mathrm{Concrete} .}
\end{aligned}
$$

Comparing the results in Table 4 to the acceptability limits in Table 1, samples 8.5.1, 8.6.3, and 8.7.3 are below the hydrogen partial density lower bound of $6.04 \mathrm{E}-02 \mathrm{~g} / \mathrm{cm}^{3}$. 


\subsection{Boron Partial Density}

Subsamples of the samples poured on 8/29/2012 were crushed, dried in an oven to remove moisture, and digested in triplicate using the ASTM method for trace metals analysis in limestone ${ }^{7}$. Aliquots of each sample were weighed in separate beakers and then $10 \mathrm{ml}$ of $\mathrm{HCl}$ and $4 \mathrm{ml}$ of $\mathrm{HNO}_{3}$ were added. The acid mixture was heated at $85{ }^{\circ} \mathrm{C}$ for 60 minutes on a hotplate, with the sample covered with a watch glass. After heating was complete, the sample cooled for an additional 60 minutes to ensure complete boron dissolution. The sample was then diluted up to a final volume of $100 \mathrm{ml}$ with deionized water. The samples were analyzed on the Agilent 730 Inductively Coupled Plasma-Optical Emission Spectrometer (ICP-OES). Boron was calibrated using a High Purity NIST traceable standard (Lot 1204016), Appendix A: Boron Certificate of Analysis. An internal standard (Yttrium) was used to compensate for matrix effects. The dissolution method prescribed in the ASTM method resulted in complete dissolution of the samples. Table 5 is the analytical results of the dissolution of colemanite concrete using the prescribed ASTM method.

Table 5. Boron Results of Colemanite Concrete Analyzed using ASTM C 1301.

\begin{tabular}{|c|c|c|}
\hline Sample ID & $\begin{array}{l}\text { Average Boron } \\
\text { Content (wt \%) }\end{array}$ & $\begin{array}{c}\text { Partial Boron Density } \\
\left(\mathrm{g} / \mathrm{cm}^{3}\right)\end{array}$ \\
\hline 8.5 .1 & 8.36 & 1.76E-01 \\
\hline 8.6 .1 & 8.82 & 1.85E-01 \\
\hline 8.7 .1 & 8.96 & 1.89E-01 \\
\hline 8.5 .3 & 8.68 & 1.83E-01 \\
\hline 8.6.3 & 8.80 & 1.83E-01 \\
\hline 8.7 .3 & 8.81 & 1.87E-01 \\
\hline
\end{tabular}

Using the calculated colemanite concrete density for each sample in Table 3, the average partial boron density is calculated. For example, the boron density of sample 8.1.1 in Reference 3 is calculated using the equations:

Mass $\boldsymbol{B}$ in $100 \mathrm{~g}$ concrete from Table $5=8.27 \mathrm{~g}$

Volume concrete $=\frac{\text { mass concrete }}{\text { density concrete }}=\frac{100 \mathrm{~g} \text { concrete }}{2.11 \frac{\mathrm{g}}{\mathrm{ml}}}=47.33 \mathrm{ml}$ concrete

$B$ density $\frac{\mathrm{g}}{\mathrm{ml}}=\frac{\text { mass } B}{\text { volume concrete }}=\frac{8.27 \mathrm{gB}}{47.33 \text { ml concrete }}=1.75 E-01 \frac{\mathrm{g} B}{\text { ml concrete }}$

\subsection{Conclusions}

The lower limits and measured values for the total density, hydrogen partial density, and boron partial density are presented in Table 6. For all the samples tested, the total density and the boron partial density exceeded the lower bounds specified in Reference 1 . The partial hydrogen density of samples 8.6.1, 8.7.1, and 8.5.3also exceeded the lower bounds specified in Reference 1. Samples 8.5.1, 8.6.3, and 8.7.3 are below the hydrogen partial density lower bound. As can be seen in Figures 1-6, the weight loss associated with free water and cement hydration released below $400{ }^{\circ} \mathrm{C}$ was lower than samples tested previously. ${ }^{3}$ The samples, as received, were not wrapped in a moist towel as previous samples and appeared to be somewhat drier. This may explain the lower hydrogen partial density with respect to previous samples. 
Table 6. Lower Bounds and Average Measured Values for the Total Density, Hydrogen Partial Density, and Boron Partial Density for the Colemanite Concrete Samples Poured 8/29/2012.

\begin{tabular}{|c|c|c|c|c|c|c|}
\hline \multirow{2}{*}{ Sample ID } & \multicolumn{2}{|c|}{$\begin{array}{l}\text { Total Density Lower } \\
\text { Bound }\left(\mathrm{g} / \mathrm{cm}^{3}\right)\end{array}$} & \multicolumn{2}{|c|}{$\begin{array}{l}\text { Hydrogen Partial Density } \\
\text { Lower Bound }\left(\mathrm{g} / \mathrm{cm}^{3}\right)\end{array}$} & \multicolumn{2}{|c|}{$\begin{array}{l}\text { Boron Partial Density } \\
\text { Lower Bound }\left(\mathrm{g} / \mathrm{cm}^{3}\right)\end{array}$} \\
\hline & Limit & Measured & Limit & Measured & Limit & Measured \\
\hline 8.5 .1 & \multirow{6}{*}{1.88} & 2.11 & \multirow{6}{*}{ 6.04E-02 } & $5.24 \mathrm{E}-02$ & \multirow{6}{*}{ 1.65E-01 } & 1.76E-01 \\
\hline 8.6 .1 & & 2.10 & & 6.35E-02 & & 1.85E-01 \\
\hline 8.7 .1 & & 2.11 & & 6.59E-02 & & 1.89E-01 \\
\hline 8.5 .3 & & 2.10 & & 6.19E-02 & & 1.83E-01 \\
\hline 8.6 .3 & & 2.08 & & $5.60 \mathrm{E}-02$ & & $1.83 \mathrm{E}-01$ \\
\hline 8.7 .3 & & 2.12 & & 5.69E-02 & & $1.87 \mathrm{E}-01$ \\
\hline
\end{tabular}

\subsection{References}

1 Wead, R., "Radiation Shielding and Fixed Neutron Absorber Panel Material and Inspection Requirements," DCS01-ZMJ-DS-SPE-M-19109-2, Revision 2, (2007).

2 " Equipment Calibration Services / Material Testing," WTA-040-8b, Section 9 (q), 4/13/2012.

${ }^{3}$ Best, D.R., Cozzi, A.D., and Reigel, M.M., "Analytical Results of MOX Colemanite Concrete Sample Poured July 25, 2012 — Cured 28 Days," SRNL-STI-2012-00543, revision 0, (2012).

4 "Standard Test Method for Density, Absorption, and Voids in Hardened Concrete," ASTM C 642-06.

5 "Standard Test Method for Compositional Analysis by Thermogravimetry," ASTM E 1131-08.

${ }^{6}$ Waclawska, I, Stoch, L, Paulik, J., and Paulik, F., "Thermal Decomposition of Colemanite," Thermochimica Acta, pp. 307-318, [126] (1988).

7 "Major and Trace Elements in Limestone and Lime by Inductively Coupled Plasma-Atomic Emission Spectroscopy (ICP) and Atomic Absorption (AA)," ASTM C 1301-95 (Reapproved 2009). 
SRNL-STI-2012-00684

Revision 1

Appendix A. Boron Certificate of Analysis 


\title{
I/ \\ wmehighoursyatandards com
}

\section{Certifícate of Analpsis}

Product Description:

$\begin{array}{llll}\text { Name: } & \text { Boron } & \text { Source Material: } & \text { Boric Acid } \\ \text { Part Number: } & 10007-4 & \text { Material Purity: } & 99.999 \% \\ \text { Lot Number: } & 1204016 & \text { Matrix: } & \mathrm{H}_{2} \mathrm{O}\end{array}$

Certified Value:

$1000 \mu \mathrm{g} / \mathrm{mL} \pm 3 \mu \mathrm{g} / \mathrm{mL}$

The Certified value is based on gravimetric and volumetric preparation, and confirmed against SRM 3107 (lot number 070514) by inductively coupled plasma optical emission spectrometry (ICP-OES) using an internal laboratory-developed method. The uncertainty in the certified value is calculated for a $95 \%$ confidence interval and coverage factor $k$ is about 2 .

Density:

$1.000 \mathrm{~g} / \mathrm{mL} \pm 0.002 \mathrm{~g} / \mathrm{mL} @ 22.8^{\circ} \mathrm{C}$

Uncertified Values:

Titration Valuet $\quad 994.97 \mu \mathrm{g} / \mathrm{mL}$

Trace Metal Impurity Scan: The data reported are based upon a scan of this specific lot at $1000 \mu \mathrm{g} / \mathrm{mL}$ via ICP analysis. The values are reported in $\mu \mathrm{g} / \mathrm{L}$.

\begin{tabular}{|c|c|c|c|c|c|c|c|c|c|c|c|c|c|}
\hline $\mathrm{Ag}$ & 0.02 & $\mathrm{Cu}$ & $<$ & 0.1 & $\mathbf{L i}$ & $<$ & I & $\mathbf{R b}$ & $<$ & $0.0 \Omega$ & Th & $<$ & 0.02 \\
\hline $\mathrm{Al}$ & 0.1 & Dy & $<$ & 0.02 & Lu & $<$ & 0.02 & Re & $<$ & 0.02 & $\mathrm{~T}$ & $<$ & 0.02 \\
\hline As & 0.05 & $\mathrm{Er}$ & $<$ & 0.02 & $\mathrm{Mg}$ & $<$ & 0.5 & $\mathbf{R h}$ & $<$ & 0.02 & $\mathrm{n}$ & $<$ & 0.02 \\
\hline Au & 0.02 & Eu & $<$ & 0.02 & $\mathrm{Mn}$ & $<$ & 0.5 & Ru & $<$ & 0.02 & $\mathrm{Tm}$ & $<$ & 0.02 \\
\hline B & $\mathrm{M}$ & $\mathrm{Fe}$ & $<$ & 5 & Mo & $<$ & 0.02 & $\mathrm{Sb}$ & $<$ & 0.02 & $\mathbf{U}$ & $<$ & 0.1 \\
\hline Ba & 0.1 & $\mathrm{Ga}$ & $<$ & 0.02 & $\mathrm{Na}$ & $<$ & 10 & $\mathrm{Sc}$ & $<$ & 0.02 & $\mathrm{v}$ & $<$ & 0.05 \\
\hline $\mathrm{Be}$ & 0.02 & Gd & $<$ & 0.02 & $\mathrm{Nb}$ & $<$ & 0.02 & $\mathrm{Se}$ & $<$ & 0.1 & w & $<$ & 0.02 \\
\hline Bi & 0.02 & $\mathrm{Ge}$ & $<$ & 0.02 & Nd & $<$ & 0.02 & $\mathbf{S i}$ & $<$ & 5 & $\mathrm{Y}$ & $<$ & 0.02 \\
\hline $\mathrm{Ca}$ & $<$ & $\mathrm{Hf}$ & $<$ & 0.02 & $\mathrm{Ni}$ & $<$ & 0.02 & $\mathrm{Sm}$ & $<$ & 0.02 & $\mathrm{Yb}$ & $<$ & 0.02 \\
\hline Cd & 0.02 & Ho & $<$ & 0.02 & Os & $<$ & 0.02 & $\mathrm{Sn}$ & $<$ & 1 & $\mathrm{Zn}$ & $<$ & 0.1 \\
\hline $\mathrm{Ce}$ & 0.02 & In & $<$ & 0.02 & $\mathrm{~Pb}$ & $<$ & 0.05 & $\mathrm{Sr}$ & $<$ & 0.02 & $\mathrm{Zr}$ & $<$ & 0.02 \\
\hline Co & 0.05 & Ir & $<$ & 0.02 & Pd & $<$ & 0.02 & $\mathrm{Ta}$ & $<$ & 0.02 & & & \\
\hline $\mathrm{Cr}$ & 0.1 & K & $<$ & 1 & $\mathrm{Pt}$ & $<$ & 0.02 & $\mathrm{~Tb}$ & $<$ & 0.02 & & & \\
\hline $\mathrm{Cs}$ & 0.02 & $\mathbf{L a}$ & $<$ & 0.02 & $\mathrm{Pt}$ & $<$ & 0.02 & $\mathrm{Te}$ & $<$ & 0.02 & & & \\
\hline
\end{tabular}

Preparation Information:

The standard solution is prepared using high purity materials and assayed by analytical methods for conformity prior to use. This standard was prepared using the methods developed at NIST for SRM Spectrometric Standard Solutions under appropriate laboratory conditions.

The matrix is 18 megaohm deionized water.

Stability of this product is based upon rigorous short term and long term testing of the solution for the certified value. This testing includes, but is not limited to, the effect of temperature and packaging on the product.

Intended Use:

This Certified Reference Material (CRM) is intended for use as a calibration standard for the quantitative determination of boron, calibration of instruments such as ICPOES, ICPMS, AAS and XRF, and validation of analytical methods. It also can be used in EPA, ASTM and other methods.

\author{
Lot No.: 1204016 \\ Rev. No: 5.00 \\ Page 1 of 2
}


Traceability Information:

The tracenbility of this standard is maintained through an unbroken chain of comparisons to appropriate standards with suitable procedure and measurement uncertainties. The maintenance of the base and derived units of International System of Units (SI) with traceability of measurement results (contemporary metrology)

to SI ensures their comparability over time as follows.

a. Standard Weight and Analytical Balance

The standard weights (NBS weights Inventory No 20231A) are calibrated every two years by South Carolina Metrology Laboratory that is a participant in "NIST Weights and Measures Measurement Assurance Program" with a certificate of measurement traceability to NIST primary standards.

The balances are calibrated yearly by the ISO 17025 accredited metrology service, and are verified weekly by an in-house method using standard weights.

b. Volumetric Device

The calibration of volumetric vessels is checked annually using the NBS 602 method.

c. Thermometer

The standard thermometers are calibrated every year by the ISO 17025 accredited metrology service. The thermometers used in-house are verified against the standard thermometers yearly.

d. Calibration Standards:

The Calibration Standard is directly traceable to SRM 3100 Series Spectrometric Standard Solutions.

Packaging and Storage Conditions:

The standard is packaged in a pre-cleaned polyethylene bottle. To maintain the integrity of this product, the solution should be kept tightly capped and stored under normal laboratory conditions.

Refer to Material Safety Datasheet (MSDS) for hazardous information.

Expiration Information:

The expiry date is guaranteed to be valid for eighteen months from the shipping date provided. For this reason, standards from the same lot may have differeat expiration dates.

$\begin{array}{ll}\text { Preparation Date: } & \text { February 9,2012 } \\ \text { Shipped Date: } & \text { MAR } 092012 \\ \text { Expiration Date: } & \text { SEP } 092013\end{array}$

Expiration Date:

February 29, 2012

Quality Information:

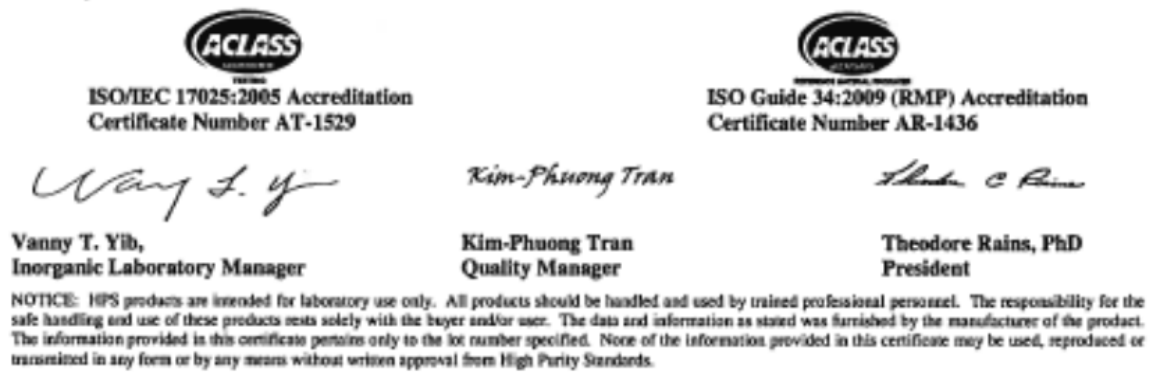

Lot No.: 1204016

Rev. No: 5.0 .0

Page 2 of 2 


\section{Distribution:}

D.R. Best, 999-W

S. D. Fink, 773-A

K.M. Fox, 999-W

B. J. Giddings, 786-5A

C. C. Herman, 999-W

S. L. Marra, 773-A

F. M. Pennebaker, 773-42A

B.R. Pickenheim, 999-W

M.M. Reigel, 999-W

J.A. Spear, 235-11F

J. P. Vaughan, 773-41A 